\title{
The Integration of the Eastern and Western Management Ideas under the Strategic Vision of Globalization
}

\author{
Yaling Li \\ Business and Tourism Management School \\ Yunnan University \\ Kunming, Yunnan, China \\ Email: 1401321642@qq.com
}

\begin{abstract}
Despite of the differences, eastern and western management ideas are essentially consistent, which is an important basis for the integration of eastern and western management ideas. In the process of integration, we not only should learn from each other's advanced management ideas, but also should be rooted in our own national conditions and the history of cultural values. At the same time, we should fully consider the market environment, economic development stage and characteristics of our own. Only in this way, the integrated management ideas can be applied in practice. In different environment and different times, the mode of integration will be different. There is no universal management idea and mode. As long as it is suitable for the national conditions, such management theory and mode is the best.
\end{abstract}

Keywords: Globalization; Management ideas; Management practice; melding

\section{INTRODUCTION}

View from the development of eastern and western management thought, due to the different social and cultural background, there are differences between the two Each has its own merits and demerits.

The requirements of economic globalization and the development of international trade make enterprises pay more and more attention to overseas market development. Economies and trade permeate each other within countries, and the world as a whole is becoming more and more interconnected. The development of oriental enterprises needs he support of the western market. The development of western enterprises also requires the support of the Oriental market. An increasing number of east and west companies are building subsidiaries in each other's countries to open up new markets.

In such a situation, the implementation of the management also gradually becomes globalization. How to manage the staffs from different nationalities, different cultural background, and how to establish effective management system in foreign special cultural background and legal system are gradually become an important proposition in the development of management.

The proper use of management ideas directly affects the development of the organization. However, because the inherent defects of eastern and western management thoughts system cannot overcome these defects on its own system, and the inherent defect will greatly affect the further development of eastern and western management ideas. This requires the eastern and western management theory study the core content of management thoughts of each other constantly, absorb the essence of each other, adapt to each other's thinking system, constantly update their management thoughts and theories according to the different market environment to adapt to the new market background.

In the context of economic globalization, the development of foreign markets and the pursuit of profit make the reference and integration of east and west management ideas inevitable.

\section{NECESSITY AND POSSIBILITY OF THE INTEGRATION OF THE EASTERN AND WESTERN MANAGEMENT IDEAS}

The requirement of economic globalization and the development of transnational trade make enterprises pay more and more attention to the development of market outside of their own country. The economy and trade between countries permeate each other. The whole world is more and more closely connected as a whole market. The development of oriental enterprises needs the support of the western market. The development of western enterprises also needs the support of the eastern market. More and more enterprises in the East and West have established subsidiary companies in the other countries to open up new markets. In this context, the implementation of management is also gradually globalized. How to manage employees with different nationalities and culture backgrounds, how to establish an effective management system under the special cultural background and legal system of foreign countries has gradually become an important proposition in the development of management. However, because the inherent defects of the eastern and western management thought system can't overcome these problems in practice by its own system, therefore. Reference and integration become the inevitable choice for the further development of East-West management thought, which requires the East-West management theory to constantly study the core content of the other side's management thought and absorb the essence of the other side. In order to adapt to the change of the new market background and to guide the development of the enterprise, the management thoughts and theories should be updated constantly according to the change of the market environment and the characteristics of the other side.

The eastern and western management thought is 
consistent in essence, which is the important foundation of the eastern and western management thought fusion. The main difference of the eastern and western management thought lies in the difference of the concrete management tools used in the management practice. The management thought has different social and cultural background and different ways and methods to solve the concrete management problems. The oriental management thought tends to be perceptual. Western management thoughts tend to be rational. What the so-called "rationality" and "sensibility" emphasize is that the concrete application of management thought is different in management practice. At the same time, the management object of eastern and western management thoughts is "human". It is based on human being and gives full play to the potential of human being for organization service. In the management of people, the western management thought adopts "hard restraint". But the eastern management thought uses the "soft constraint" more often, and "the soft constraint" may form the cultural restriction through the development. The final cultural constraint will also have the effect of "hard constraint", and "hard constraint" can also produce special culture in the organization through long-term action and influence, forming the effect of "soft constraint". The mechanism of "soft constraint" and "hard constraint" is not fixed. The roles and effects between them can be transformed under certain conditions. Therefore, the difference between eastern and western management thought is mainly the difference in content, and there is no fundamental contradiction and conflict in the core and purpose of management thought. The integration of eastern and western management ideas is feasible and grounded.

\section{MODALITIES OF INTEGRATION}

Different nationalities, countries, and enterprises have different backgrounds and face different problems. The integration of eastern and western management thoughts is neither the logic of the original Oriental management thought nor the logic of the western management thought, but the formation of a new logic. So we can't fully apply the original logical framework and analytical method in the eastern and western management ideas, but we should insist on the common basic of the eastern and western management thoughts, in the management practice, according to the concrete situation, creatively merge the eastern and western management thoughts to serve for the organization.

Because of the great differences between the eastern and western management thoughts, it is obviously not an easy task to merge the two ideas. In a word, we should integrate the management thoughts of East and West which formed due to different cultures, take the essence of the management, discard the dross, and infiltrate each other, integrate each other, and learn from each other. Finally, the integration of eastern and western management thoughts is realized, and the management thought which adapts to the common development of Chinese and western management under the background of globalization is formed.

\section{A. The Integration of Western Management Thoughts in Oriental Management Thoughts.}

First, last days the management concept with soft constraint by ethic is not popular anymore, China begins to standardize system and clarify discipline. Second, China begins to introduce the western competitive mechanism, instead of focusing on interpersonal harmony. The introduction of market competition mechanism accords with the rules of survival of the fittest, which have motivated human behavior, promoted human progress, created a fairer environment and made the organization run more efficiently. Third, China begins to pay attention to the status of the individual in the group but not only related to the collective interests, also introduced an incentive mechanism, pay attention to the potential of the individual, pay attention to personal progress and success, individual potential has exploited fully. Finally, innovation is an important part of the core competitiveness of enterprises and the key to the long-term survival of enterprises. China also pays more and more attention to and encourages innovation, and is constantly innovating.

\section{B. The Integration of Oriental Management Thoughts in Western Management Thoughts.}

First, it is the trend of the evolution from materiality to humanism in the west. As a result of the emergence of many abuses in Western society, the western management community began to attach importance to human beings. Now the learning organization put forward by the west is the embodiment of the spirit of "people first" in oriental culture. Second, on the basics of rigid management with strict rules and regulations, the west incorporated the element of flexible management in oriental management. Now the flexible management proposed by the west is based on this. Third, rather than attaching importance to competition, the west began to turn to consideration of competition and cooperation. Competition is necessary, but the competition without cooperation is the most likely to the intensify contradictions, resulting in the loss of both sides, the emergence of a zero-sum model. The strategy of cooperative competition and the emphasis on corporate social responsibility and sustainable economic development are the concrete manifestations of the emphasis on cooperation. Fourth, in the past, the west emphasized individualism, but now it has begun to focus on interpersonal harmony. In fact, group harmony is very important to the development of individuals, because harmonious enterprises can improve the mood of those involved in the organization and Make it serve the organization better, also realize the organization benefit more finally.

\section{TRENDS IN THE FUTURE INTEGRATION OF EASTERN AND WESTERN MANAGEMENT IDEAS}

Geographical factors have created different cultures in East and West, and formed two completely different management theories. Oriental management ideas attach importance to the emotion factors of people, with mainly moral soft constrain. It focuses on groups over individuals 
and pay attention to the harmony of the whole, also with strong sense of political. Western management thought from the beginning to treat people as things, in the process of development it slowly began to pay attention to the emotional needs of people, with the system of unified planning, utilitarian, focus on the individual over the group The importance of "rule of law" and the effectiveness of "rule by virtue" should be recognized by both East and West in the context of global economic integration. Western culture, which should be characterized by "rational tools" and oriental culture characterized by "value rationality", should intersect, infiltrate, merge and draw from each other. History has developed to the present The East began to pay attention to the establishment of rules and regulations, not only rely on morality, but also began to attach importance to the individual needs of people and pay attention to competition; The West has also introduced the flexible management of the East, focusing on the needs of human beings. Western ecological management, green management, sustainable development management, knowledge-based organization, learning organization and the management of enterprise culture are all influenced by the harmonious thought of the east and is the expression of the fusion of the western management thought and the oriental thought.

Globalization makes future management more uncertain, more fuzzy, more complex and more rapid and changeable, which brings great challenges to organizational management. It makes it difficult to set management goals, the design of management mechanism is not complete, the management operation process is difficult to design, and people's behavior can't be controlled. The wisdom of East-West management in dealing with the above challenges reflects different management ideas and logical ideas. The two are complementary. If they can be effectively integrated, they can better provide a new way to deal with the challenges in the future management research and practice. Therefore, there is still a lot of room for integration of eastern and western management ideas. Its future is bound to achieve integration and development in more areas.

\section{V.THE CONCLUSIONS}

With the development of economic globalization, the increasingly frequent exchanges between the East and the West. Western companies need to learn the oriental management experience, Oriental enterprises also need to learn from western management experience, the integration of Chinese and Western management thoughts have met the needs of scholars and entrepreneurs, more and more widely promoted in society, but also the inevitable trend of Chinese and Western management theory development.

In a word, whether it is Chinese management, west management, or the combination of east and west management, there is no perfect management theory and mode. In the context of global integration, to meet the needs of scholars and entrepreneurs, the integration of eastern and western management thoughts is increasingly becoming the direction and outlet of the development of oriental management thought and mode in the future. The formation of Chinese management mode is a process of integration and innovation of eastern and western management thoughts. It reflects the development of oriental management and western management, and the current China to the global and the construction of a harmonious society, as to the value-oriented requirements of the management theory and practice, its goal is to continue to promote the harmonious development of human beings, man and society, man and nature.

However, in the process of studying and researching the western management thought, we should not only learn from the western advanced management thoughts, but also take root in the oriental special national conditions and the cultural values of historical heritage. At the same time, we should fully take into account the domestic market environment, economic development stage and characteristics, so that the integrated management ideas can be applied in practice. In different environments and different periods, the integration model will also be different, in this sense, there is no universal management thought and mode, the fittest is the best. In every different stage of development, as long as the management theory and model are suitable for our national conditions, it is the best.

\section{REFERENCES}

[1] Peter Drucker: management challenges of the 21st Century. [M] .Beijing: mechanical Industry Press, China, 2009.

[2] Du Rong, Cathalta Brugha. The comparison of Eastern and Western Management theories under the Framework of the Theory of thought: exploring the way of the Chinese School of Management Science to the World. [J] .Beijing: Journal of Management, 2017, (10)

[3] Li Ting. A Comparative study of Management Theory and Cultural Management in China and East. [J] .Beijing: modernization of shopping malls, 2012, (22)

[4] Su Zongwei, Fan Zheng, Su Dong-shui, Wang Feng-hua--Review of the views of the 17th World Management Forum and Oriental Management Forum. [J] .Beijing: managing the world in 2014, (1).

[5] Su Zongwei, Fan Zheng, Su Dongshui, Wang Fenghua. The Development of Oriental Management Theory and practical Innovation in the era of Great change: a Summary of the views of the 18th World Management Forum and Oriental Management Forum. [J] .Beijing: managing the world in 2015, (1).

[6] Zhao Xiaokang, Yang Yuhong, Yuan Huiting. Theoretical thinking and practical Innovation of Oriental Management under the New normal: a Summary of the views of the 19th World Management Forum and Oriental Management Forum. $[\mathrm{J}]$.Beijing: managing the world in 2016, (1). 